\title{
"Illegal" Pawns for "Immoral" Loans: Testing the Limits of the Monti di Pietà in Late Fifteenth-Century Tuscany
}

PAOLA PINELLI

University of Florence

Les archives toscanes contiennent une importante documentation illustrant divers aspects des premières années des prêteurs sur gages des Monti di Pietà. On y trouve de riches informations sur le sexe et le statut des emprunteurs, sur les montants empruntés, sur les intérêts, ainsi que sur les conditions de rachat des effets mis en gage. Certaines archives - celles du monte de Prato par exemple - contiennent des registres dans lesquels les comptables du monte inscrivaient les opérations "interdites", dont l'existence ne devait pas apparaître dans les registres officiels. Ces registres privés contiennent des entrées qui font état de mises en gage de biens atypiques, telles que des biens précieux, qui, selon les lois, ne pouvaient être reçus en gage en retour de prêts, étant donné que ces emprunteurs n'appartenaient pas au groupe social désigné comme "nécessiteux et pauvre ». Par ailleurs, des gages étaient également donnés en échange d'argent, qui n'était pas utilisé pour les premières nécessitées, mais bien plutôt dépensé pour des activités "immorales " telles que les jeux de hasard et les aventures galantes.

$I^{\prime}$ n Tuscany most of the institutions that we know of as monti di pietà were founded in the years between 1466 and 1476. ${ }^{1}$ Unfortunately, the archives of these monti are often discontinuous and present major gaps. In what would otherwise be a generally discouraging situation, a notable exception is represented by the archives of the monti di pietà of Arezzo (1473) and Prato (1476), which have an extraordinary wealth of documents. In particular, the archives of the Monte of Prato not only contain statutes and accounting records, but also two extraordinary notebooks of the first administrators of the monte, Girolamo di Lorenzo Talducci and Andrea di Duccio d'Andrea. These are described by their authors as quaderneti da mano, that is, little handbooks that were small enough to be held in one hand and easily hidden in the folds of one's clothing. ${ }^{2}$ Talducci, who was quite an enterprising individual and often appears in 
documents as an administrator of public funds, mentions the fact that these little notebooks were of a very personal nature and were used to write down everything of importance so that he could defend himself against any accusations of wrongdoing. ${ }^{3}$

The particular purpose of the monti, their public nature, and the fact that their function was guaranteed by monetary funds established by the Comune meant that they were subject to the most rigid supervision by municipal authorities in order to limit the spread of illegal practices. This was implemented through a series of measures that were meant to prevent theft and control fraud. Night watchmen guarded the goods deposited with the monte, and there were incentives for those who reported thefts and fines for those who acted illegally. ${ }^{4}$ Above all, crosschecking procedures followed by the accountants of the Comune were supposed to verify that the entries in the monte's ledgers had not been falsified or altered in any way for the purpose of committing fraud. It was perhaps for this reason that monte officials in Prato, like Girolamo di Lorenzo Talducci and Andrea di Duccio d'Andrea, began to keep private parallel ledgers that would be useful in case it became necessary to demonstrate the propriety of their actions. In these notebooks they wrote down detailed accounts of all the operations that were only summarized in the ledgers of the monte, like the expenses incurred or the frequent changes of large currency into small coins, which was necessary for making loans. They also recorded the advances paid to the administrators and workmen of the monte to whom, according to the statutes, salaries could be paid only after the accounts had been reviewed. ${ }^{5}$ Sometimes it was necessary to write down operations that were secret but were important to remember in case one was called to account for one's actions. Examples of this include loans that had been granted without collateral, or loans guaranteed by pawns that were either forbidden by the statutes or meant for some purpose that was not strictly legal.

This brief paper deals with some of these "illegal" pawns and "immoral" loans. They represent a means of testing the limits of the earliest monti di pietà in order to verify if, and to what extent, the ideas and objectives expressed in the monte statutes were actually observed, and to determine with a certain degree of precision the real activities of the institution. The administrators, as we shall see, frequently broke the rules of the statutes. However, they saw the monte not only as a form of charity for the poor, but also as a vehicle for cultivating good social relations in the community at large. In the logic of the common 
good and public interest, good relations were fundamental for consolidating and rationalizing the economic resources of the institution. As a result, in most of these cases breaking the rules did not constitute fraud or corruption but rather flexibility.

The rules contained in the statutes that governed the first Tuscan monti di pietà did not vary much from city to city. Archives of the monti frequently contain statutes from neighbouring towns, suggesting that officials took ideas, inspiration, and administrative details from each other. So, for example, the monte di pietà of Pistoia had copies of the statutes of both the Monte Pio of Montepulciano and the Monte of Siena, and officials probably used them as a basis for drawing up their own statutes in Pistoia. ${ }^{6}$

Statutes commonly insisted that the monte should assist the poor in order to free them from the threat of usury by the Jews. The institution was intended to be not a charitable agency but an organization that was to be managed according to economic principles meant to assure its survival over time. Those who used it, therefore, were the needy (bisognosi), sometimes also defined as chalamitosi ("calamity-stricken") or miserabili ("impoverished"). These terms described persons who were able to work but lived in extremely precarious conditions, due to the lack of a steady job and with working hours that were conditioned by the vagaries of weather, seasonal shifts in demand, and the shorter working days of winter. They were the untrained labourers who worked in the fields or at building sites in the city in exchange for a salary that was so low it was not enough to pay for even the most basic necessities; who, in any case, were unable to save or set aside money to tide them over during hard times. The monte therefore could not make loans to beggars or vagabonds, or to people with no income, who would certainly be unable to repay the loan and would hence endanger the financial equilibrium of the institution. A Memorandum of 1572 of the Florentine Monte states that officers were to lend money only to borrowers who could prove that they owned some property. The evidence of this might be the officer's own prior knowledge, a report by the Rectors, or the testimony of people. No loans were made to people without some form of property offered as collateral. ${ }^{7}$

In any case, the persons receiving the loans had to be included in the census or entered in the registry of citizens, and the issuing of the loan had to be for honest purposes. It could not be used by craftsmen or tradesmen to solve temporary cash shortages; otherwise they would risk losing the pawn. The 
monte di pietà should not loan money for any kind of gambling nor to anyone who wanted the money for some kind of commerce, "but only to the impoverished for their needs and honest necessities." ${ }^{8}$ Lending must be transparent, and so loans could not be negotiated outside of the premises of the monte. The statutes of the Monte of Prato stated that the loan had to be negotiated in rooms at the city hall, and that the money of the monte was dispensed here because it was a public place. ${ }^{9}$

The Libro del Depositario of Arezzo shows that from October 1476 to March 1478, 1911 clients came from either the city or the surrounding countryside (contado). ${ }^{10}$ Most of them were men ( 74 percent) and in the majority of cases (71 percent) their profession is not specified. This suggests that most belonged to the class of impoverished day labourers. Craftsmen represented 16.6 percent of the total borrowers; most worked in the textile or tanning sector. Small merchants and shopkeepers, such as millers, bakers, and grocers, represented a further 6.6 percent. From the objects that were pawned it is not possible to know the reasons for these loans. Given the small scale of household-based enterprises at the time, it is very difficult to distinguish the needs of the business from the needs of the family. Business and family finances were often confused, and in personal ledgers private and commercial accounts were recorded without making any distinction between the two. About 5 percent of borrowers in Arezzo were professionals who received a salary or performed services (messengers, customs officials, household servants, municipal guards and purchasers, soldiers, doctors, scribes, tutors, domestics or shop boys), while a very small percentage ( 0.8 percent) were ecclesiastics. In Prato the situation was similar. From January to July 1477,1890 people took out loans. More than 81 percent were men, and we do not know the profession of 76 percent of them. Craftsmen, working mostly in the textile sector, made up 12.5 percent of the total borrowers, and small merchants made up a further 3.3 percent. Only 1.3 percent were ecclesiastics. All of the borrowers registered in these six months were from the city of Prato.

There were strict regulations on the kinds of objects that could be pawned. Consecrated or blessed objects to be used during the mass were prohibited. In order to avoid having tailors and drapers pawn goods that did not belong to them, it was prohibited to pawn any unfinished piece of clothing or remnant of cloth or piece of drapery without permission from the guild. ${ }^{11}$ At Arezzo, records show that the items most frequently pawned were household linens 
(about 40 percent), mostly tablecloths of all shapes and sizes, but also towels, sheets, handkerchiefs, and pillow cases. The pieces recorded were, in any case, textiles of little value, and were often described as being in very poor condition. The clothes that were pawned (33.4 percent) must have been in an equally sorry state and consisted mainly of cloaks, various male and female garments, ${ }^{12}$ caps, hoods, and sleeves which, since they were particularly subject to wear, were made to be removable. Only 14.2 percent of the goods pawned in Arezzo in this period were lengths of textile, particularly linen cloth (50 percent), and they were often moth-eaten or nibbled by rats. In 5.4 percent of cases, household utensils and furniture were pawned: mortars, soup dishes, plates, metal pots, ewers, and flatware; but also pillows, towels, and quilts. It is somewhat puzzling to see that tools were also pawned. This included not only tools related to farming activities, such as axes, hoes, and spades, but also craftsmen's utensils such as saws, hammers, hatchets, and anvils. In these cases, however, we are not able to determine clearly whether there was a direct relation between the tool that was pawned and the profession of the person who pawned it; it is possible that some of these tools had been stolen or pilfered and that they were now being disposed of. It is even more puzzling to observe that among the objects pawned there were cintole, or belts or girdles decorated with precious metals (about 3 percent of the objects), as well as ingots and other objects made of gold and silver (3.6 percent) such as ewers, flatware, buckles, ferrules, buttons, little crosses, and rings, sometimes set with stones. The value of these objects suggests that they represented a modest family heirloom which had been scrupulously preserved until a situation arose that could not be resolved with ordinary resources. ${ }^{13}$

In Prato as well, the objects most often pawned were household linens and clothing (26.4 and 33 percent respectively). The former consisted mostly of fabrics, with large rough linen cloths prevailing (22.6 and 8.5 percent). In 5 percent of cases we find objects and various types of vessels; and in 4.5 percent, valuable objects - mostly rings and buttons worth a significant amount of money. It should be recalled that there was a set maximum amount that could be loaned (three florins in Arezzo, which was about the equivalent of sixteen lire in Prato). Only one-quarter of the loans were for an amount in excess of three lire, an amount which, in a period of high prices, barely purchased two months' worth of bread. ${ }^{14}$ 
The ledgers in Arezzo and Prato therefore bear out the rules set out in the statutes: these monti, at least in their earliest years, did not make loans to beggars and did not grant financing for commercial ventures. They helped poor people who pawned goods of little value in order to pay the modest sums required for their daily expenses.

But were things really like that? As mentioned earlier, the handbooks of Prato would seem to show that the money belonging to the institution was sometimes used for purposes that were not listed in the statutes, and that the officers sometimes behaved in ways that might be defined as irregular.

In 1477, in the six months during which Talducci was depositary of the Monte of Prato, two "immoral" loans were granted. The first was to Giovanni di Guasparo da Gello, a blacksmith who worked as a guard inside the monte, in order to pay off some gambling debts. The second was to Bartolomeo di Michele Ferri, who was also one of the guards at the monte, in order to pay his expenses at a brothel. In both cases the amount loaned was two lire. ${ }^{15}$ Numerous loans without pawns were made as advances to employees of the monte (154 of the roughly 4350 loans made in the period), and the employees used them to buy meat or to pay for bread or wine. In the case of Bartolomeo Ferri mentioned above, a loan allowed him to pay for a candle to be lit during festivities honouring the shoemakers' guild to which he belonged. ${ }^{16}$ On March 20, 1477, Leone di Lodovico Cambioni, rector of the monte, received one florin which he claimed was to be used to allow his son Giuliano to take holy orders as a priest. ${ }^{17}$ Even Talducci himself took a loan from the Monte, although in order to save appearances it was issued to a stand-in, Niccolao di Nanni Pinucci. One month later he borrowed another eight lire, and the loan was again issued to Pinucci, who pawned for the shoemaker two silk girdles with silver trim. ${ }^{18}$ In the same way, when the treasurer Andrea di Duccio wanted a loan of sixteen lire eight soldi in February 1484, he took it out in the name of Francesco di Marco di Tato, and registered the pawn of two gold rings. ${ }^{19}$

While the statutes of the Monte of Prato emphasized giving loans for basic subsistence rather than for business investment, the shoemaker-administrator Girolamo di Lorenzo Talducci frequently lent money without pawns to craftsmen and shopkeepers in order to support their businesses; there are about 80 such transactions in his private register. In only four cases were these loans granted to fellows of the shoemakers' guild, such as Girolamo di messer Girolamo who borrowed nine lire to purchase leather. ${ }^{20}$ On March 24, 1477, 
the tanner Bartolomeo di Leonardo di Giunta received one florin to purchase leather; four days later Bernardo di Giovanni di Quilico, who was one of the eight officials who had drafted the rules of the monte, received more than 34 lire for the same purpose. ${ }^{21}$ On April 30, Andrea di Stefano Foresi, who also belonged to the shoemakers' guild, received a loan of two lire which he used to write a letter to the merchant's court (Tribunale della Mercanzia). On May 1, 1477, Talducci himself took a loan of almost four lire from the monte in order to organize a party for guild members. ${ }^{22}$

Moreover, Talducci frequently bent the rules on where and how to lend money, on accepting pawn items that the statutes clearly forbade, or on taking pawns whose value suggested that the owners were not labourers scrabbling on the edges of marginality. In May of 1477, his notebook includes an entry registering a gown of red satin embroidered with pearls that was pawned as a pledge against a loan of six lire to Giovanni di Lorenzo Manzi, a monk at the Carmino; ${ }^{23}$ there is no corresponding written record in monte ledgers since, as we have seen, this kind of security was severely forbidden by the statutes. When the loan was repaid just fifteen days later, the monte did not even charge interest on it. On February 14, 1477, Giorgio di Meo di Duccio received three florins in his own shop and promised that he would repay the sum within two days or else send a pledge to the monte. The object to be pawned was a damask girdle trimmed with silver, with seven buckles. ${ }^{24}$ On March 18, Girolamo di Lorenzo Talducci in his own house loaned 60 lire to a grocer, Antonio di Vannozzo di Piero, using money from the monte. As security he accepted a brocade girdle with gilded silver trim weighing seven ounces which, however, he did not write down in the pawn register but rather kept for himself. ${ }^{25}$ In his personal notebook, the treasurer Andrea di Duccio di Andrea also records loans where valuable pawns such as a diamond ring or, more often, girdles trimmed with silver were kept at his own house rather than in the monte's quarters. ${ }^{26}$

To summarize briefly, we can observe that both Girolamo di Lorenzo Talducci and Andrea di Duccio d'Andrea, as officials of the Monte of Prato, frequently broke the rules of the statutes by financing the more or less honest needs of the employees of the monte, by sustaining small manufacturing or commercial activities, and by lending money to prominent citizens. In his notebook, Andrea di Duccio also recorded that, when he was camarlingo of the Monte, he made an excellent deal by acquiring from the Jewish money-lender Salomone 
d'Abramo nine silk and silver girdles, a green and black saia (a light cloth), a purple gamurra, an ordinary gold ring, a ring with a ruby, a ring with a pearl, a ring with a garnet, and two silver forks, all for the sum of 28 florins; these were items that Salomone had as pawns. ${ }^{27}$ So we have a sharp contrast between tight regulations and loose enforcement.

On the other hand, from Talducci's notebook we learn that the people behind Prato's monte were not particularly concerned about whether taking or giving interest constituted usury. Even in the first year of activity the administrators accepted deposits with interest, a practice that was officially possible only five decades later when the Tuscan monti were formally transformed into important institutions in the credit structure which went well beyond their initial activity of issuing loans against pawns. ${ }^{28}$ During the first years of activity in the late 1470s, the Monte of Prato also charged an unusually high interest, amounting to three denari per month for each lira or 15 percent per annum. It was lowered to 5 percent - generally considered by the statutes as a fair rate for covering the costs in this type of institution - only in 1493, when the monte's experience reduced its fears of a financial imbalance. ${ }^{29}$ Something similar, for example, happened in the Monte of Florence, where the officials initially imposed a rate of 10 percent per annum, and reduced it to 5 percent only a few years later. The Monte of Prato was charging an interest of three denari per lira per month even when the object was redeemed the same day or after a few days: this meant that, on an annualized basis, interest rates for the client could be very high, reaching over 500 percent in some cases. At the Monte of Arezzo the administrators charged not only the 5 percent interest rate set out by the statutes, but also a commission of four denari, regardless of the time of repayment or the amount of the loan. This meant that on short-term loans they were charging an interest rate that, calculated on an annualized basis, was over 90 percent. $^{30}$

The statutes of the Monte of Prato stated that total loans could not exceed 475 lire in a week. If we reconstruct the weekly cash flow of the monte in the first year of activity, we see that the officials exercised great caution in following this limit. Even during periods traditionally characterized by an increase in consumption, such as the days close to major feast days, they did not exceed the limit and always ensured that the monte carried a surplus. ${ }^{31}$ The monte was a new institution, and administrators like Girolamo di Lorenzo Talducci and Andrea di Duccio were responsible for ensuring its success by preventing 
poor or careless management of its funds. In the case of these "illegal" pawns and "immoral" loans, they bent the rules discreetly so as not to damage the image of an institution from which one would expect a degree of severity. At the same time, they intended to cultivate and to maintain the good social relations that were fundamental to the continued activities of the monte. The officials saw the monte not just as a form of charity for the poor, but also as a vehicle for communal economic development and health. On June 21, 1477, Girolamo lent the large sum of 40 florins to Cipriano di Stefano Niccolucci and Lorenzo di Giuliano del Boncio, administrators of the city's granary (Canova), in order to buy grain for the Comune in a famine period. There is no corresponding written record in monte ledgers and the loan was negotiated outside the monte premises. On June 26, only five days later, the loan was repaid in the house of Girolamo; he did not even charge interest on it. ${ }^{32}$ Clearly, "rule breaking" went far beyond lending money to employees to go to a brothel.

For the same reasons, the loans to small tradesmen and craftsmen should for the most part not be interpreted as the pursuit of personal gain, but rather as actions within an economy based on favours, friendships, and profits that helped to consolidate and rationalize the economic resources of the monte and advance the city's economy. In the absence of other records, we cannot say for certain whether the actions of these officials constituted fraud or flexibility. Certainly in the four cases of loans made to guild brothers, they stood to gain social capital from their actions, and also stood to lose face, social capital, and influence if they refused requests for loans. However, the fact that these first administrators also accepted interest-bearing deposits, established unusually high interest rates, and adopted a cautious policy on the concession of loans suggests that they were aware of the greater potential of the monte di pietà as an economic resource in their community, and that they acted in order to expand that potential. Their actions frequently bent the rules, but were consistent with the general purpose of guaranteeing the stability and continuity of the monte, and advancing the common good and public interest.

\section{Notes}

1. The Monte of Sansepolcro was founded in 1466, and was soon followed by that of Montepulciano in 1467, those of Cortona and Siena in 1472, Arezzo and Pistoia 
in 1473, San Giovanni Valdarno in 1474, and Prato in 1476. Several years later similar institutions were founded in Lucca (1488), Volterra (1492), Pisa (1495), and, finally, in Florence (1496). To date, an organic study of the monti di pietà in Tuscany does not exist; there are only monographs or essays of local interest. For Arezzo, see Maria Giovanna Cutini-Gheri and Antonella Moriani, Le carte dei Monti Pii dell'Archivio di Stato di Arezzo (Arezzo: Provincia di Arezzo, 1986); for Firenze, see Marino Ciardini, I banchieri ebrei in Firenze nel secolo XV e il Monte di Pietà fondato da Girolamo Savonarola (reprint Firenze: Libreria Gozzini, 1970) and Carol B. Menning, Charity and State in Late Renaissance Italy: The Monte di Pietà of Florence (New York: Cornell University Press, 1993); for Lucca, see Domenico Corsi, Il secondo Monte di Pietà di Lucca (1493-1502) (Firenze: L. S. Olschki, 1968); for Pisa, see Marcello Berti, "Note sull'organizzazione e sull'amministrazione del Monte di Pietà di Pisa (secoli XVI-XVIII)," in Credito e sviluppo economico in Italia dal Medioevo all'Età Contemporanea, Atti del I Convegno Nazionale della Società Italiana degli Storici dell'Economia, 4-6 giugno 1987 (Verona: Fiorini 1988), pp. 307-23; for Pistoia, see Ilvo Capecchi and Lucia Gai, Il Monte della Pietà a Pistoia (Firenze: L. S. Olschki, 1976); for Prato, see Giulio Giani, "Saggio di una storia del Monte Pio del comune di Prato," Archivio Storico Pratese, III-IV (1927); for Volterra, see Michele Luzzati and Alessandra Veronese, Banche e banchieri a Volterra nel Medioevo e nel Rinascimento (Pisa: Pacini, 1993).

2. Archivio di Stato di Prato (hereafter A.S.Po.), Ceppi, 1525, 1528.

3. See also the introduction to another of Girolamo di Lorenzo Talducci's little handbooks, where he notes: "E scriveròcci tutte chose d'inportanza per chi mi volesse mai dare noia di nulla per potermi difendere" (A.S.Po, Ceppi, 2290, n. 2, c. 1r).

4. A.S.Po., Comunale, Istituti Pii, 3, c. 7r.

5. A.S.Po., Comunale, Istituti Pii, 3, c. 8v.

6. Archivio di Stato di Pistoia, Raccolte del Comune, 5, cc. 57-63; 6, cc. 358-64.

7. 'Gli imprestiti de' denari che alla giornata da questo Monte di Pietà si fanno a diverse persone, per la maggior parte son fondati in su la conoscenza che hanno gli ufficiali che li contraenti sieno benestanti o su la relazione che ne danno li rettori del dominio o su le fede delle persone de' beni che son descritti alla posta nel dì che si fa l'imprestito, non si prestando a chi non ha beni; et in questo modo il Monte vien sicuro, 'sendoli tali beni sempre obligati" (Archivio della Cassa di Risparmio di Firenze, 950, c. 32r).

8. 'Non presteranno e' danari del prefato Monte della Pietà de' Poveri ad alchuno giuchatore che per giuchare gli volesse nè anchora ad alchuno el quale potessino 
intendere che in qualunque modo d'essi danari volesse fare alchuna merchantia, ma solo a' poveri pe loro bisogni et necessità honeste" (A.S.Po., Comunale, Istituti Pii, 3, c. 3r, but see also Archivio di Stato di Arezzo [hereafter A.S.Ar.], Statuti e Riforme, 1, XIIII; Archivio di Stato di Firenze [hereafter A.S.Fi.], Monte di Pietà, Statuti, IX).

9. A.S.Po., Comunale, Istituti Pii, 3, c. 2r but see also A.S.Ar., Statuti e Riforme, 1, XXV.

10. Clients and pawned objects of the monti di pietà of Prato and Arezzo are studied in Paola Pinelli, "Tra città e cortine: pegni e impegnanti del Monte Pio di Arezzo alla fine del Quattrocento," in press.

11. A.S.Po., Comunale, Istituti Pii, 3, c. 8r but see also A.S.Ar., Statuti e Riforme, 1, XVIII; A.S.Fi., Monte di Pietà, Statuti, XXVI.

12. These garments are mostly gamurre (or gammurre), guarnelli and giornee, women's clothing with modest fabric and finishings; cioppe (often characterized by a cap), rather simple tunics for both males and females, also used as an undergarment; lucchi, large coats, tight at the waist, mainly used in the Florentine area.

13. Paola Massa, "Artigiani, credito e Monti di Pietà: l'esempio di Savona alla fine del Quattrocento," in Aspetti della vita economica medievale, Atti del Convegno di Studi nel X anniversario della morte di Federigo Melis, Firenze-Pisa-Prato 10-14 marzo 1984 (Firenze: E. Ariani e L'arte della stampa, 1985), pp. 538-39.

14. Paola Pinelli, "Prices and Salaries in a Tuscan Town in the Century of the Black Death," in A Critical Re-Examination of Demographic and Economic Crises in Western Europe During the Period of the Ancien Régime and Nineteenth Century, Fifteenth World Economic History Congress, Utrecht 2009, August 5, Session C5; Paola Pinelli, “The Diet of the Rest," in Francesco di Marco Datini: The Man, the Merchant, ed. Giampiero Nigro (Firenze: Firenze University Press, 2010), p. 121.

15. A.S.Po., Ceppi, 1525, cc. 10r, 13r.

16. A.S.Po., Ceppi, 1525, c. 3v.

17. A.S.Po., Ceppi, 1525, c. 4v.

18. A.S.Po., Ceppi, 1525, c. 21r. The record specified that one of the girdles was in black damask for a woman and the other was for a man.

19. A.S.Po., Ceppi, 1528, c. 46v.

20. A.S.Po., Ceppi, 1525, c. 6v.

21. A.S.Po., Ceppi, 1525, c. 5r.

22. A.S.Po., Ceppi. 1525, c. 7r. 
23. "Un chorporale di raso chermisi richamato chon perli" (A.S.Po., Ceppi, 1525, c. $8 \mathrm{v})$.

24. "Una cintola fornita d'ariento, fetta di tane in domaschino, chon sette cignitoi" (A.S.Po., Ceppi, 1525, c. 2v).

25. "Una cintola di brochato fornita d'ariento dorato pesò on. 7 ... la quale cintola non è altrimenti scritta a Libro de’ Pegni ma abialla apreso a noi" (A.S.Po., Ceppi, 1525, c. $4 \mathrm{r})$.

26. A.S.Po., Ceppi, 1528, cc. 30, 31.

27. A.S.Po., Ceppi, 1528, c. $61 v$.

28. Paola Pinelli, "Ragguagliare ai tempi debiti le partite dell'entrate et uscite: la contabilità dei Monti Pii toscani tra XV e XVI secolo," in I conti dei Monti. Teoria e pratica amministrativa nei Monti di Pietà fra Medioevo ed Età Moderna, ed. Mauro Carboni and Maria Giuseppina Muzzarelli (Venezia: Marsilio, 2008), p. 128.

29. See Giani, "Saggio di una storia del Monte Pio."

30. Pinelli, "Ragguagliare ai tempi debiti," p. 115 and also Pinelli, "Tra città e cortine."

31. Pinelli, "Ragguagliare ai tempi debiti," pp. 115, 117.

32. A.S.Po., Ceppi, 1525, cc. 11v, 12r. 